\title{
Assessment of potential biogas production from rice straw leachate in upflow anaerobic sludge blanket reactor (UASB)
}

\author{
Nurul Shafiqah Rosli*, S. Idrus, Nik Daud N., A. Ahsan \\ Department of Civil Engineering, Faculty of Engineering, University Putra Malaysia, 43400 Serdang, Selangor, Malaysia
}

\begin{abstract}
This study evaluates the potential of Rice Straw Leachate (RSL) to generate biogas and investigate its biodegradability by determining the differences between the theoretical yield and the actual one at its increasing organic loading rate. Seven litre working volume of Up-Flow Anaerobic Sludge Blanket (UASB) reactor is employed under mesophilic condition at temperature of 38 for approximately 17 consecutive weeks. The process performance was evaluated based on the efficiency of COD removal and Specific Methane Production (SMP) in relation to the other parameters such as $\mathrm{pH}$, Organic Loading Rate (OLR), Total Ammonia Nitrogen (TAN) and alkalinity ratio. The OLR were varied at $0.43,0.55,0.9$ and $1.55 \mathrm{~g} \mathrm{COD} / \mathrm{L} / \mathrm{d}$ with average COD removal of $79 \%, 81.2 \%, 76.1 \%$, and $75.8 \%$ respectively. The stability of anaerobic digestion of RSL in UASB was found maintained at an increasing OLR with indicator of $\mathrm{pH}$, TAN and IA/PA ratio that always maintain in the range of $6.5-6.8$, below $200 \mathrm{mg} / \mathrm{L}$ and 0.3 respectively. Meanwhile, the optimum average SMP and COD removal efficiency were $0.18 \mathrm{~L} \mathrm{CH}_{4} \mathrm{~g}^{-1} \mathrm{COD}_{\text {rem }}$ and $81.2 \%$ respectively, at applied OLR of $0.55 \mathrm{~g} \mathrm{COD} / \mathrm{L} / \mathrm{d}$. This study also revealed a relatively high deviation of SMP from its theoretical value, indicating its low degradability and the limitation of nutrient factors present in RSL.
\end{abstract}

Keyword: Anaerobic digestion, chemical oxygen demand, rice straw leachate, specific methane production

\section{Introduction}

The growing of population and rapid industrial development are the main contributors for the increasing trend in global energy demand [1], and currently, about $88 \%$ of this demand is met by fossil fuels utilization [2]. However, concerning the issues related to the continuous exhaustion of existing fossil fuel reserves, the rising cost for crude oil, as well as the global warming impact (a result of fossil fuels combustion), many researchers all over the world have an urges to find the alternative of fossil fuels which is suitable, feasible, economic, sustainable and environmental friendly [3]. In this context, biogas (mixture of methane and carbon dioxide) in the form of renewable energy, produced by Anaerobic Digestion (AD) of organic matters can become a great replacement for fossil fuels thus hold an important role in the future [2].

Among the numbers of existing biomass resources available to produce biogas (such as, agricultural crops and residues, industrial wastes, municipal solid waste, and sewage waste), municipal sludge from waste-water treatment plants is currently the main source used [4]. Nevertheless, recently the abundance amount of agricultural residue produced, such as rice straw with global production of about 731 million tons annually, has become an important subject as a source of fuel for energy generation [1], [5], as improperly managed such organic wastes the same as wasting a potential energy value at once threatening the environmental quality. Currently, an open-field burning is one of the most common practice of handling rice straw by the farmers after the harvesting period in many countries in Asia including Malaysia [1], [6], [7], due to its feasible process, inexpensive and there are no markets for straw [8]. However, this activity can give a bad health effect towards children and patients with asthma particularly, as particles produced by the rice straw burning can easily invade the lungs causing a respiratory disease.

\footnotetext{
${ }^{*}$ Manuscript rece6ived April 5, 2016; revised June 30, 2016.

Corresponding author. Tel.:+6013-3154015; E-mail address: nurulshafiqah.rosli@gmail.com

doi: $10.12720 /$ sgce.5.3.135-143
} 
Moreover, rice straw burning can result a severe environmental pollution such as air pollution as well as the increase of greenhouse gases ( $\mathrm{GHG})\left(\mathrm{CO}_{2}, \mathrm{CH}_{4}, \mathrm{SO}_{2}\right.$ and nitrogen oxide) emission, which has been identified to be the main causes of global warming over the last 50 years [9]-[11].

Besides that, some other conventional disposal options such as incorporated the straw with soil is also not recommendable as it will cause the reducing of crop yields due to degradation of soil condition and the increased of foliar disease [12], at the same time generates between 2.5 and 4.5 times more methane than burning the straw [8], [13], [14]. Thus, AD can become one of the promising sustainable alternatives for the disposal management of rice straw due to the production of renewable energy (biogas) as a byproduct [11]. GHG could also be reduced from biogas utilization compared to fossil fuels. Apart from biogas production, the mineralized effluent obtained from $\mathrm{AD}$ can be utilized as a bio-fertilizer with high concentrations of nitrogen, phosphorus and potassium (NPK) [15]. However, as rice straw is a lignocellulosic material containing cellulose (37.4\%), hemi-cellulose (44.9\%), lignin (4.9\%) and silicon ash $(13.1 \%)$, it will cause the difficulties during the degradation process as ligno-carbohydrate complexes thus become an obstacle for microbial conversion [16], [17]. Hence, many types of pre-treatment have been undertaken in order to enhance the $\mathrm{AD}$ of rice straw such as physical, chemical, biological, $\mathrm{pH}$, temperature and etc. [18] but not all are practical, feasible and typically energy efficient to be applied in industrial sector [17].

Therefore in this study, the organic wash water or known as rice straw leachate (RSL) extracted from the raw rice straw might hold the potential for biogas production with a simple pre-treatment technique. Besides, none of the previous studies have investigated biogas potential from AD of RSL. For that reason, the objective of this paper is to evaluate the potential of RSL to generate biogas and investigate its biodegradability rate by determining the differences between the theoretical methane yield and the actual one at its increasing OLR. AD has been chosen to be the suitable method for the treatment of RSL, as it is associated with a low operational cost, low sludge production, and also the methane produced as the byproduct of the process could be used as an energy source for power and heat generation, as well as gaseous vehicle fuel [19], [2].

\section{Materials and Methods}

\subsection{Substrates and inoculum}

The rice straw used in the study was collected from paddy field located at Jempol, Negeri Sembilan. It was preselected in order to remove particulate components which include fine stones. Subsequently, the rice straw was dried and cut up into approximately uniform length before it was soaked in tap water. The $\mathrm{RSL}$ is produced in a ratio of $18 \mathrm{~g}$ of dried rice straw to 1 litres of tap water and left for soaking at least for a week.

Table 1. Compositions of synthetic wastewater preparation in 1L volume [20]

\begin{tabular}{|c|c|}
\hline Materials & Amount \\
\hline Yeast (granular form) & $23 \mathrm{~g}$ \\
\hline Urea & $2 \mathrm{~g}$ \\
\hline Sugar & $11.5 \mathrm{~g}$ \\
\hline Full cream milk & $144 \mathrm{~mL}$ \\
\hline Blood & $5.75 \mathrm{~mL}$ \\
\hline Tap water & Make up volume until 1L \\
\hline
\end{tabular}

Meanwhile, synthetic wastewater as explained by Idrus et al., [20] was used as a substrate during acclimation period as it allowed the use of a consistent ingredient of control feedstock with high biodegradability. The materials used for synthetic sewage preparation are shown in Table 1 below. On the other hand, the activated sludge used were originated and collected from wastewater treatment plant at Faculty of Engineering, University Putra Malaysia. 


\subsection{Analytical methods}

The parameters tested in the influent and effluent (treated influent-product from reactor) will allow the determination of the efficiency of the reactor in treating the waste as well as producing the biogas as a renewable energy. During the reactor operation, biogas production were monitored and recorded daily as well as for parameters such as, $\mathrm{pH}$ and COD. Meanwhile, total alkalinity and total ammonia nitrogen were determined once per week. The analysis were performed in duplicate in order to ensure the consistency of the readings. All parameters were determined according to standard method for the examination of water and wastewater [21].

Biogas production were monitored and recorded daily using the water displacement method, through water acidified or known as acidified brine solution. Brine solution preparation was referred as method suggesting by Iyagba et al., [22] where $\mathrm{NaCl}$ will be added to water until supersaturated solution form. Then, followed by a few drops of $\mathrm{H}_{2} \mathrm{SO}_{4}$ to acidify the brine solution. On the other hand, for the determination of biogas composition, the analysis was performed using Agilent Technology, 6890N Network Gas Chromatography System.

\subsection{Experimental set-up}

AD of RSL was conducted using 7L working volume of up-flow anaerobic sludge blanket (UASB). UASB was fabricated using opaque polyvinyl chloride (PVC) sheet solid with the following dimensions: $87 \mathrm{~cm}$ internal diameter and $11 \mathrm{~cm}$ height with a cylindrical shaped. The reactor set-up as shown in Fig. 1.

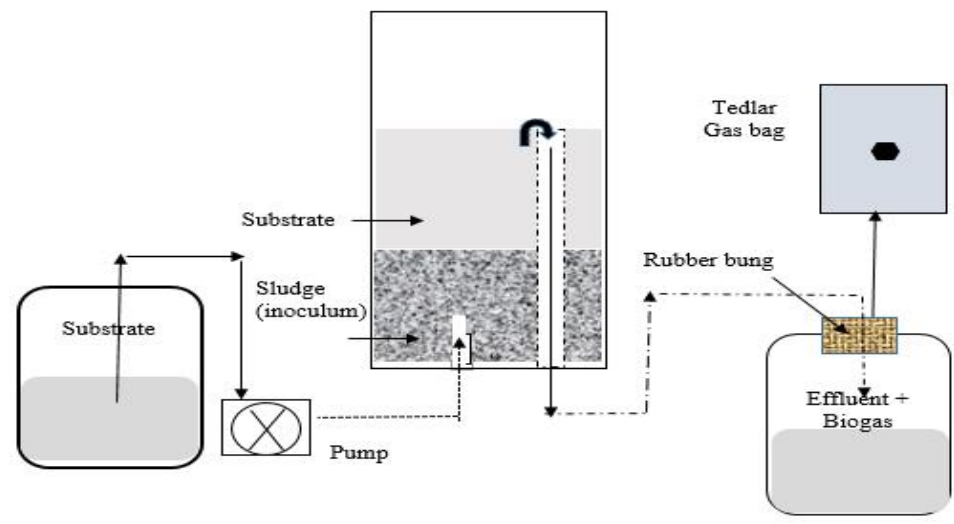

Fig. 1. Experimental UASB set-up.

The reactor has two ports for each influent and effluent at its bottom part. The influent was fed into the digester by a solenoid driven dosing pump. Whereas, the effluent and the produced gas ware collected into the sealed effluent container connected with Tedlar gas sampling bag. The UASB is heated by water bath method to mesophilic condition at temperature of 38. For the start-up, the digester was seeded with activated sludge at mesophilic condition. The synthetic wastewater was fed into the reactor on daily basis with OLR of $0.43 \mathrm{gCOD} / \mathrm{L} /$ day and hydraulic retention time (HRT) of 1 day until the steady state condition was achieved (constant removal of COD) before substituting the feeding with RSL at increasing OLR. Table 2 shows the five phases of AD of RSL performed in this study.

Table 2. UASB reactor operating condition during experimental work

\begin{tabular}{|c|c|c|c|}
\hline Phase & Days & Feedstock & OLR (g COD/L/d) \\
\hline I & Acclimation (1-40) & Synthetic wastewater & 0.43 \\
\hline II & $41-65$ & RSL & 0.43 \\
\hline III & $66-93$ & RSL & 0.55 \\
\hline IV & $94-118$ & RSL & 0.90 \\
\hline V & $119-138$ & RSL & 1.55 \\
\hline
\end{tabular}




\section{Result and Discussion}

\subsection{Characterization of rice straw leachate and synthetic wastewater}

Both substrates RSL and synthetic wastewater were analysed immediately after prepared. The characteristics of RSL as stated follows: COD 2200mg/L; Total Nitrogen 48mg/L; pH 6.54; Total alkalinity $571 \mathrm{mg} / \mathrm{L} ; \mathrm{K} 319 \mathrm{mg} / \mathrm{L} ; \mathrm{Na} 56 \mathrm{mg} / \mathrm{L} ; \mathrm{Zn}$ n.d and $\mathrm{Cu}$ n.d. The characteristics of synthetic wastewater are: COD 2200mg/L; Total Nitrogen $80 \mathrm{mg} / \mathrm{L}$. Both RSL and synthetic wastewater were stored at 4 to avoid the deterioration of sample

\subsection{UASB reactor performance on anaerobic digestion of rice straw leachate}

\section{pH}

$\mathrm{pH}$ is one of the important parameter in biogas production management as indicator for degree of stability. Fig. 2 shows the pH distribution over 138 days of experiments. In general, throughout the experiments, $\mathrm{pH}$ of the effluent at all phases were maintained at above 6 , with no additional of caustic chemicals for $\mathrm{pH}$ adjustment or to maintain process stability. At the beginning of the experiments, where the acclimation phases took placed, the synthetic wastewater was fed into the UASB. Graph showed a fluctuation of $\mathrm{pH}$ with the minimum and maximum reading of 6.08 and 6.85 respectively, and maintained at 6.65 until the feeding was switched with RSL. The increase of $\mathrm{pH}$ to the optimum may be contributed by the lower starting OLR applied which is $0.43 \mathrm{~g} \mathrm{COD} / \mathrm{L} / \mathrm{d}$ indicating the good start-up or acclimation process in the reactor. Phase II was started at day 41 with RSL feeding at OLR of $0.43 \mathrm{~g} \mathrm{COD/L/d}$. The declining of $\mathrm{pH}$ from 6.67 to 6.56 was observed when the feeding was changed from synthetic wastewater to RSL as the sudden switch of feeding might cause a disturbance in the AD system.

A fast recovery was observed, as on day 43 , the $\mathrm{pH}$ was back to 6.67 and continuously increased up to 6.85. Throughout the remaining phases (III, IV, V), when the OLR of RSL were increased to 0.55, 0.9 and $1.55 \mathrm{~g} \mathrm{COD} / \mathrm{L} / \mathrm{d}, \mathrm{pH}$ distribution showed no significant increase or decline and just maintained in the range of 6.6-6.8. According to Ward et al., [23], and Cioabla et al., [24], range $\mathrm{pH}$ of 6.8-7.2 was found to be optimal for AD process, and tolerable at a range of 6.5-8.0. Meanwhile, Labatut and Gooch, [25] stated that $\mathrm{pH}$ in range 6.5-7.6 are the accepted range of $\mathrm{pH}$ for an efficient $\mathrm{AD}$ and it is in line with Liu et al., [26] whom stated that the optimum $\mathrm{pH}$ range is between 6.5 to 7.5 though the optimal range might be varied depends on the substrates and digestion technique used. Thus, this indicates that the AD of RSL in UASB was stable and well buffered throughout the experiment and able to achieve the steady state condition at the increasing OLR.

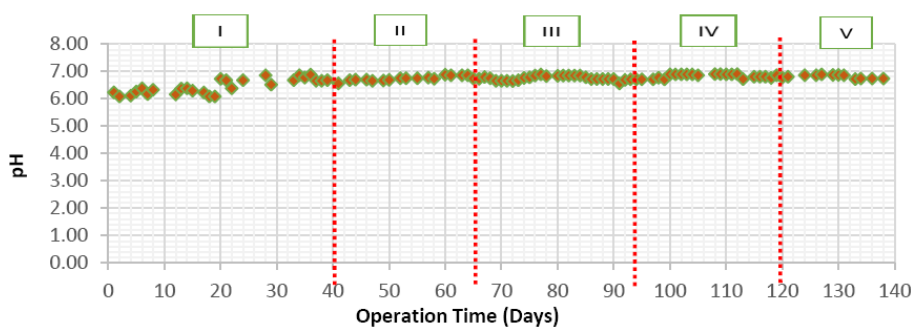

Fig. 2. Distribution of $\mathrm{pH}$.

\section{Ammonia nitrogen and IA/PA ratio}

Fig. 3 represents the variation of total ammonia nitrogen (TAN) and alkalinity ratio. Ammonia Nitrogen (AN) is one of the important factors which are known to cause a toxic effects and complete failure of methanogenesis thus towards AD system [27]. According to Franke-Whittle et al., [27] ammonia nitrogen can cause inhibition towards methanogenesis at concentration of $1.7 \mathrm{~g} / \mathrm{L}$ and above. From the graph, generally TAN concentration was seen to be increased as the OLR was increased. 
However, there is no significant difference of TAN at phase II and phase III due to small differences of OLR applied. The significant increment of TAN at phase IV and V indicating the increased of nitrogen or protein concentration presented in the RSL as the OLR was increased [28]. Even though there is a significant increase of TAN as OLR was increased up to $1.55 \mathrm{~g} / \mathrm{L}$, but the value is still below the values which can inhibit the AD process. Instead, at TAN concentration of below than $200 \mathrm{mg} / \mathrm{L}$, it is considered as beneficial for the process $\mathrm{AD}$, as ammonia generally is utilized as source of food for methanogens organisms which speeding up for granules activities in the methanogenic phase [29].

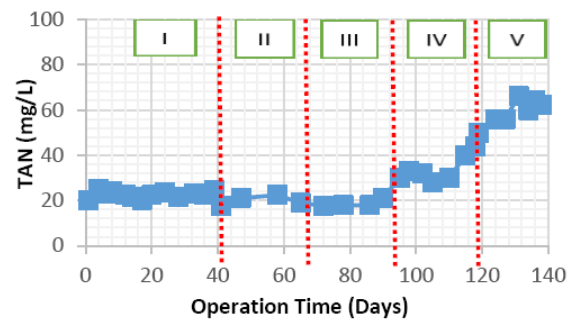

(a)

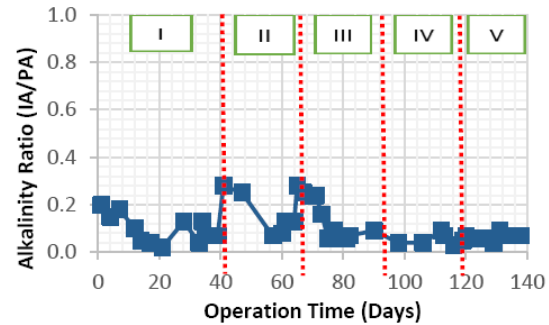

(b)

Fig. 3. (a) Ammonia nitrogen distribution. (b) IA/PA ratio distribution.

The proper alkalinity maintenance in UASB reactor is very important to provide the sufficient buffering capacity to withstand the moderate shock loads of volatile fatty acids [25]. Alkalinity can be related to alkalinity ratio, which also known as intermediate alkalinity over partial alkalinity (IA/PA) [30]. Fig. 3(b) shows the IA/PA ratio distribution over 17 consecutive weeks of the experimental work. The value of IA/PA was observed to be always maintained below 0.3 at all phases indicating a good stability of the system during the process of AD of RSL [31]. This is parallel with what has been reported by Ripley et al., [32] and Franco et al., [33] that the ratio between intermediate alkalinity to partial alkalinity must maintain at a value lower than 0.3-0.4 for an adequate performance of $\mathrm{AD}$.

\subsection{The removal of $C O D$ and specific methane production}

In $\mathrm{AD}$, the $\mathrm{COD}$ removal can be related with the production of biogas, as the conversion of organic contents into methane. The performance of UASB reactor in the COD removal efficiency, specific biogas production (SBP) and Specific Methane Production (SMP) throughout the experiment are shown in Fig. 4 with the different phases being defined in Table 2. At all phases, a similar pattern of SBP and SMP could be seen. During the first week of phase I, there was a fluctuation and the obvious sudden decrease of COD removal rate indicating the methanogenic microorganism are still adapting themselves towards the applied environment and the incoming organic load which also known as an acclimation period. The subsequent weeks show the steady increment of COD removal with the highest removal rate of $95.6 \%$. Corresponding to COD removal, the SMP also increasing as COD removal increased with the highest methane production of $0.33 \mathrm{~L} \mathrm{CH}_{4} \mathrm{~g}^{-1} \mathrm{COD}_{\text {rem }}$. Starting at day 41, the feeding was switched with RSL at the same OLR applied during the acclimation period. It resulted in an immediate decrease of COD removal rate to $77.5 \%$ with the corresponding SMP of $0.15 \mathrm{~L} \mathrm{CH}_{4} \mathrm{~g}^{-1} \mathrm{COD}$ (Fig. 4). The significant decrease of COD removal rate and SMP could be due to the sudden change of feedstock from synthetic wastewater to RSL. However, after over two consecutive weeks feeding with RSL at OLR of $0.43 \mathrm{gCOD} / \mathrm{L} / \mathrm{d}$, the removal rate of COD as well as SMP was improved and remain steady at $82 \%$ and $0.16 \mathrm{~L} \mathrm{CH}_{4} \mathrm{~g}^{-1} \mathrm{COD}$ respectively, indicating a stability of the digester and the achievement of steady state on that specific OLR.

Starting on day 66 , the OLR was increased to $0.55 \mathrm{gCOD} / \mathrm{L} / \mathrm{d}$. The increase of OLR cause a bit changes in the performance, as COD removal rate was observed to decrease to $63 \%$ from $82 \%$ with SMP of $0.14 \mathrm{~L} \mathrm{CH}_{4} \mathrm{~g}^{-1} \mathrm{COD}$. However, it does not take a long time for the reactor to achieve the steady removal rate of COD as the removal remained at $80-84 \%$ from day 80 to 93 with the highest SMP of $0.18 \mathrm{~L} \mathrm{CH}_{4} \mathrm{~g}^{-1} \mathrm{COD}$. The shorter time required to achieve the steady removal of COD as well as methane 
yield were due to the slight differences of OLR applied, whereby the methanogenic microorganism are already acclimatized to that specific range of organic loading. Moreover, the increased of SMP and COD removal rate, could be explained by the stable degradation of the substrate in diluted sample to stabilize the anaerobic degradation [34]. By day 65 , the OLR of RSL was increased up to $0.9 \mathrm{gCOD} / \mathrm{L} / \mathrm{d}$ and the removal rate of COD had fallen significantly to $65.54 \%$ together with SMP of $0.09 \mathrm{LCH}_{4} \mathrm{~g}^{-1} \mathrm{COD}$. The SMP was reduced to about half of maximum yield obtained in the phase III. Despite having a sudden decrease of COD removal rate, it was then recovered by a gradual increase of removal rate and achieved the stable state at day 113 with $78-79 \%$ removal rate. The same goes for SMP, the increase up to 0.13L $\mathrm{CH}_{4} \mathrm{~g}^{-1} \mathrm{COD}$ was observed at the end of the day of phase IV.

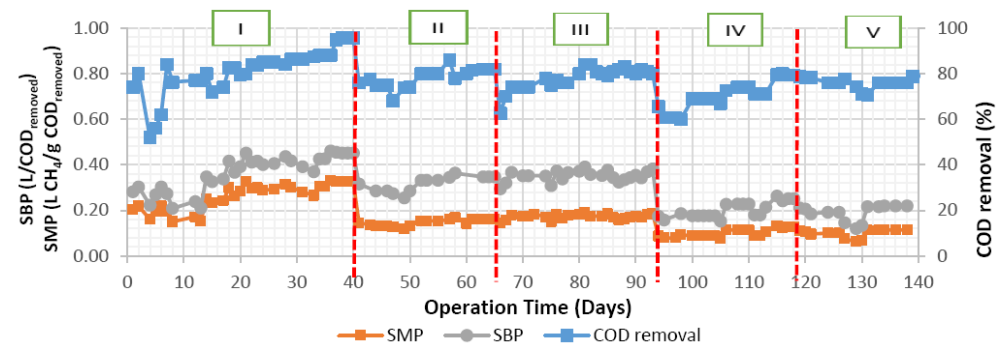

Fig. 4. Distribution of COD removal, specific methane production and specific biogas production at different phases.

Meanwhile, at day 119 the similar trend of COD removal rate were observed when the OLR was raised to $1.55 \mathrm{gCOD} / \mathrm{L} / \mathrm{d}$. There is a slight decrease of COD removal rate as well as SMP before the reading recovered and maintained at a steady value. At phase IV and V, the removal rate of COD were found consistent with both phase II and III. In contrast, the SBP and SMP were decreasing as to compare with phases II and III. This could be due to a higher hydrolysis but less methanogenesis, as hydrolytic bacteria are more robust towards environmental condition [35]. To summarize, at the beginning of each phases, the decrease of COD removal rate and SMP were detected and recovered shortly after every OLR change. The increase of OLR from 0.43 to $1.55 \mathrm{gCOD} / \mathrm{L} / \mathrm{d}$ able to maintain the removal rate of COD from 75 $82 \%$ indicating the suitable system of the acclimatized UASB for handling RSL at a variable OLR feeding. This would be consistent with the finding by Puyol et al., [36] whom reported that the UASB reactor showed the stable behaviour on $\mathrm{AD}$ of cosmetic wastewater after the acclimation period with the average of COD removal efficiency between $78-85 \%$. Moreover, the already acclimatized microbes towards the higher OLR could be explained as to why the stable state removal of COD was achieved in a shorter period of time.

\subsection{Biodegradability of rice straw leachate}

The performance of biodegradability rate of RSL was studied by calculating the differences between the theoretical with the real production of methane in the experiments. The theoretical SMP in relation to $\mathrm{COD}$ as has been reported by Grady et al., [37] is, $0.35 \mathrm{~m}^{3} \mathrm{CH}_{4}$ per $\mathrm{kg}$ of COD removed with the production of biogas of about $0.5 \mathrm{~m}^{3} / \mathrm{kg}$ COD removed. Table 3 presenting the deviation of methane production from its theoretical value at all different phases.

Table 3. Comparison of the SMP for synthetic wastewater and RSL at different OLR

\begin{tabular}{|c|c|c|c|c|}
\hline Phase & $\begin{array}{c}\text { Average COD removal } \\
(\%)\end{array}$ & $\begin{array}{c}\underset{1}{\text { Average SMP }\left(\mathrm{L} \mathrm{CH}_{4} \mathrm{~g}^{-}\right.} \\
\left.{ }_{\mathrm{COm}}\right)\end{array}$ & $\begin{array}{c}\text { Theoretical } \mathrm{CH}_{4}{ }^{\mathrm{a}}(\mathrm{L} \\
\left.\mathrm{CH}_{4} \mathrm{~g}^{-1} \mathrm{COD}_{\mathrm{rem}}\right)\end{array}$ & $\begin{array}{l}\text { Deviation of } \mathrm{CH}_{4}{ }^{\mathrm{b}} \\
\left(\mathrm{L} \mathrm{CH}_{4} \mathrm{~g}^{-1} \mathrm{COD}_{\mathrm{rem}}\right)\end{array}$ \\
\hline I & 91.0 & 0.31 & 0.34 & 0.03 \\
\hline II & 79.0 & 0.16 & 0.28 & 0.12 \\
\hline III & 81.2 & 0.18 & 0.28 & 0.10 \\
\hline IV & 76.1 & 0.11 & 0.26 & 0.15 \\
\hline V & 75.8 & 0.10 & 0.26 & 0.16 \\
\hline
\end{tabular}


Among all phases studied, acclimation with synthetic wastewater shows a higher production of methane with a small deviation from its theoretical value of only $0.05 \mathrm{~L} \mathrm{CH} 4 \mathrm{~g}^{-1} \mathrm{COD}_{\text {rem. }}$. It was as projected because synthetic wastewater used is known for its high biodegradability [20]. In contrast, by comparing the phases feeding with RSL, the average SMP was found higher at phase III with the applied OLR of $0.55 \mathrm{~g} \mathrm{gCOD} / \mathrm{L} / \mathrm{d}$. The higher the OLR of RSL, the higher the deviation of volume methane production from its theoretical value, indicating the low degradability of RSL as a substrate. Even though the leachate was fed instead of raw rice straw, but the small portion of rice straw which is lignocellulosic in nature still present as a dross or flakes in a leachate. The higher the organic loading rate of RSL would also increase the presence of lignin and it tended to accumulate and cause difficulties for degradation in AD process [16], [38].

In addition, the low total nitrogen content of RSL could also become the contributor towards the decrement in methane production. According to Dioha et al., [39], the carbon to nitrogen (C:N) ratio of the substrate can greatly affect the biogas production, where the optimum ratio was reported range from 25-35 [17]. In this study, the measured ratio of COD: Total nitrogen is 46:1 indicating the imbalance C:N ratio of RSL. This founding is in line with the previous studies done on raw rice straw, which stated that the untreated rice straw has a very low concentration of total nitrogen which eventually affecting the nutrient balance for the optimum biogas production [16], [40], [17].

\subsection{The sludge morphology}

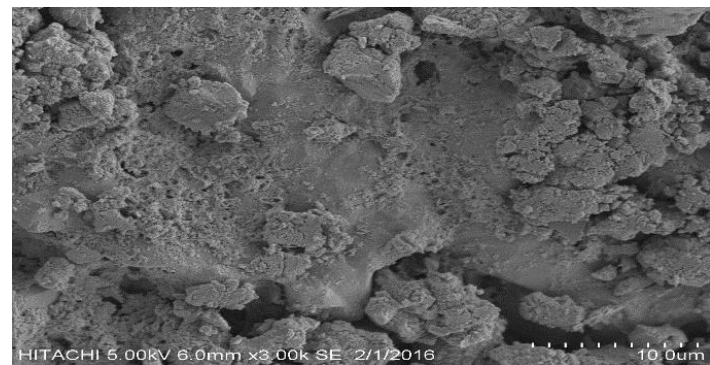

(a)

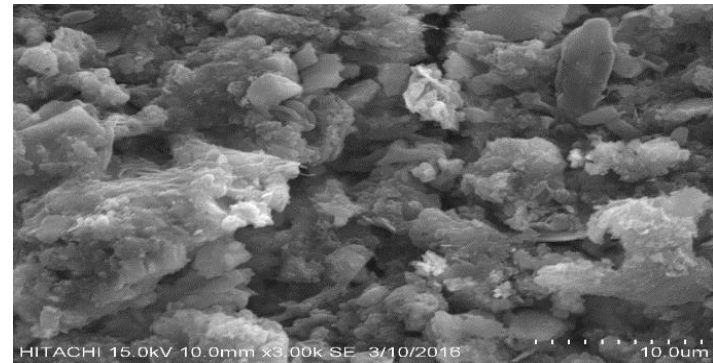

(b)

Fig. 5. SEM image of the sludge inoculum (a) before feeding started (b) formation of fine granules after 100 days of operation.

Fig. 5 represent the scanning electron microscope (SEM) image of the inoculum sludge before and after the feeding with RSL. After 100 days of feeding, it can be seen the finer activated sludge has become more compact with the formation of granules. The sludge washout has decreased significantly due to the granulation and result in a good performance of UASB in COD removal rate specifically. The development of sludge granulation is one of the important factors contributed towards the successful operation in UASB [41]. This finding is consistent with the founding by Zhao et al., [42] and Wu et al., [43], whom reported that the pollutants removal efficiency (i.e: COD) was improved by utilizing the granular sludge in wastewater treatment and the size of sludge granule could be proportional with the production of biogas.

\section{Conclusions}

The process $\mathrm{AD}$ of $\mathrm{RSL}$ at a variety OLR from $0.43 \mathrm{gCOD} / \mathrm{L} / \mathrm{d}$ to $1.55 \mathrm{gCOD} / \mathrm{L} / \mathrm{d}$, was able to maintain the stability of a system operated in UASB reactor with indicator of $\mathrm{pH}$, TAN and IA/PA ratio that always maintain in the range of $6.5-6.8$, below $200 \mathrm{mg} / \mathrm{L}$ and 0.3 respectively. During the feeding of RSL, the highest average of COD removal efficiency found was $81.2 \%$ with SMP of $0.18 \mathrm{~L} \mathrm{CH}_{4} \mathrm{~g}^{-}$ ${ }^{1} \mathrm{COD}_{\text {rem }}$ at OLR $0.55 \mathrm{gCOD} / \mathrm{L} / \mathrm{d}$. Relatively, the varied OLR of RSL has a substantial influence on biogas as well as methane yield. Nevertheless, a higher organic loading rate could still be applied as the 
system did not showed any sign of overloading at $1.55 \mathrm{gCOD} / \mathrm{L} / \mathrm{d}$. However, at a higher OLR, the low degradability of RSL content might has a significant effect on the optimum amount of biogas production and resulted in a low methanogenic potential. Generally, the results indicate that, RSL was found to hold the potential for biogas production. However, the imbalance C:N ratio and the low degradability of RSL might cause a restriction towards the optimum production of biogas. The co-digestion of RSL with the other substrates that contain a high degradability properties could be proposed for the optimum production of biogas.

\section{Acknowledgment}

The authors thank the Fundamental Research Grant Scheme (FRGS) funded by Ministry of Higher Education Malaysian Government, vot number of 5524615 for providing the financial support in conducting this study.

\section{References}

[1] Lim JS, Manan ZA, Alwi SR, Hashim H. A review on utilisation of biomass from rice industry as a source of renewable energy. Renewable and Sustainable Energy Reviews, Jun 30, 2012; 16(5):3084-94.

[2] Weiland P. Biogas production: current state and perspectives. Applied Microbiology and Biotechnology, Jan 1, 2010; 85(4):849-60.

[3] Mohammed MAA., Salmiaton A, Azlina WW, Amran MM, Fakhru'l-Razi A, Taufiq-Yap YH. Hydrogen rich gas from oil palm biomass as a potential source of renewable energy in Malaysia. Renewable and Sustainable Energy Reviews, 2011; 15(2):1258-1270.

[4] Börjesson P, Mattiasson B. Biogas as a resource-efficient vehicle fuel. Trends in Biotechnology, Jan 31, 2008; 26(1):7-13.

[5] Hosseini SE, Abdul WM. The role of renewable and sustainable energy in the energy mix of Malaysia: a review. International Journal of Energy Research, Nov. 1, 2014; 38(14):1769-92.

[6] Shafie SM, Masjuki HH, Mahlia TM. Life cycle assessment of rice straw-based power generation in Malaysia. Energy, Jun 1, 2014; 70:401-10.

[7] Rosmiza MZ, Davies WP, Rosniza Aznie CP, Mazdi M, Jabil MJ. Farmers' knowledge on potential uses of rice straw: an assessment in MADA and Sekinchan, Malaysia, Geografia: Malaysian Journal of Society and Space, 2014; 10(5):30-43.

[8] Fitzgerald GJ, Scow KM, Hill JE. Fallow season straw and water management effects on methane emissions in California rice. Global Biogeochem. Cycles, Sep. 1, 2000; 14(3):767-76.

[9] Shuit SH, Tan KT, Lee KT, Kamaruddin AH. Oil palm biomass as a sustainable energy source: a Malaysian case study. Energy, Sep. 30, 2009; 34(9):1225-35.

[10] Lianhua L, Dong L, Yongming S, Longlong M, Zhenhong Y, Xiaoying K. Effect of temperature and solid concentration on anaerobic digestion of rice straw in South China. International Journal of Hydrogen Energy, Jul. 31, 2010; 35(13):7261-7266.

[11] Menardo S, Cacciatore V, Balsari P. Batch and continuous biogas production arising from feed varying in rice straw volumes following pre-treatment with extrusion. Bioresource Technology, Mar 31, 2015; 180:154-61.

[12] Zhang R, Zhang Z. Biogasification of rice straw with an anaerobic-phased solids digester system. Bioresource Technology, Jun 30, 1999; 68(3):235-45.

[13] Liou RM, Huang SN, Lin CW. Methane emission from fields with differences in nitrogen fertilizers and rice varieties in Taiwan paddy soils. Chemosphere, Jan 31, 2003; 50(2):237-46.

[14] Said N, Bishara T, García-Maraver A, Zamorano M. Effect of water washing on the thermal behavior of rice straw. Waste Management, Nov 30, 2013; 33(11):2250-2256.

[15] Díaz JP, Reyes IP, Lundin M, Horváth IS. Co-digestion of different waste mixtures from agro-industrial activities: kinetic evaluation and synergetic effects. Bioresource Technology, Dec. 31, 2011; 102(23):10834-10840.

[16] Hills DJ, Roberts DW. Anaerobic digestion of dairy manure and field crop residues. Agricultural Wastes, Jul 31, 1981; 3(3):179-189.

[17] Mussoline W, Esposito G, Giordano A, Lens P. The anaerobic digestion of rice straw: a review. Critical Reviews in Environmental Science and Technology, Jan 1, 2013; 43(9):895-915.

[18] Lei Z, Chen J, Zhang Z, Sugiura N. Methane production from rice straw with acclimated anaerobic sludge: effect of phosphate supplementation. Bioresource Technology, Jun 30, 2010; 101(12):4343-8.

[19] Noyola A, Morgan-Sagastume JM, Lopez-Hernandez JE. Treatment of biogas produced in anaerobic reactors for domestic wastewater: odor control and energy/resource recovery. Reviews in Environmental Science and Bio/Technology, Feb 1, 2006; 
5(1):93-114

[20] Idrus S, Banks CJ, Heaven S. Assessment of the potential for biogas production from wheat straw leachate in upflow anaerobic sludge blanket digesters. Water Science \& Technology, 2012; 66(12):2737-2744.

[21] American Public Health Association. APHA. Standard Methods for the Examination of Water and Wastewater, 21th ed. Washington: APHA, 2005.

[22] Iyagba ET, Mangibo IA, Mohammad YS. The study of cow dung as co-substrate with rice husk in biogas production. Scientific Research and Essay, Sep 1, 2009; 4(9):861-6.

[23] Ward AJ, Hobbs PJ, Holliman PJ, Jones DL. Optimisation of the anaerobic digestion of agricultural resources. Bioresource Technology, Nov. 30, 2008; 99(17):7928-7940.

[24] Cioabla AE, Ionel I, Dumitrel GA, Popescu F. Comparative study on factors affecting anaerobic digestion of agriculturalvegetal residues. Biotechnology for Biofuels., Jun 6, 2012 ;5(1):1.

[25] Labatut RA, Gooch CA. Monitoring of anaerobic digestion process to optimize performance and prevent system failure. In: Proc. of Got Manure? Enhancing Environmental and Economic Sustainability, Mar 28, 2012:209-225.

[26] Liu CF, Yuan XZ, Zeng GM, Li WW, Li J. Prediction of methane yield at optimum pH for anaerobic digestion of organic fraction of municipal solid waste. Bioresource Technology, Mar 31, 2008; 99(4):882-888.

[27] Franke-Whittle IH, Walter A, Ebner C, Insam H. Investigation into the effect of high concentrations of volatile fatty acids inanaerobic digestion on methanogenic communities. Waste Management, Nov 30, 2014; 34(11):2080-2089.

[28] Hughes K, Simon M, inventors. High-nitrogen loading for ammonia processing via anaerobic digestion. United States patent application US 13/739,855. 2013 Jan 11.

[29] Habeeb SA, Latiff AA, Daud ZB, Ahmad ZB. A review on granules initiation and development inside UASB Reactor and the main factors affecting granules formation process. International Journal of Energy and Environment, 2011; 2(2):311-20.

[30] Drosg B. Process monitoring in biogas plants. In: Proc. of IEA Bioenergy. 2013.

[31] Rodrigues LS, Silva IJ, Oliveira PR, Pinto AC, Lima CA. Influence of the ratio IA/PA and volatile acids in the monitoring of UASB reactor in the treating of swine waste water. Journal of Water Resource and Protection, Apr. 1, 2014; 6(5):526.

[32] Ripley LE, Boyle WC, Converse JC. Improved alkalimetric monitoring for anaerobic digestion of high-strength wastes. Journal (Water Pollution Control Federation), May 1986; 1:406-11.

[33] Franco A, Mosquera-Corral A, Campos JL, Roca E. Learning to operate anaerobic bioreactors. University of Santiago de Compostela, 2007.

[34] Ghani WA, Idris A. Preliminary study on biogas production of biogas from municipal solid waste (MSW) leachate. Journal of Engineering Science and Technology, Dec. 2009; 4(4):374-80.

[35] Babaee A, Shayegan J. Anaerobic digestion of vegetable waste. Sharif University of Technology, 2010;1-6.

[36] Puyol D, Monsalvo VM, Mohedano AF, Sanz JL, Rodriguez JJ. Cosmetic wastewater treatment by upflow anaerobic sludge blanket reactor. Journal of Hazardous Materials, Jan 30, 2011; 185(2):1059-1065.

[37] Grady Jr CPL, Daigger GT, Lim HC. Biological Wastewater Treatment, 2nd edn, Marcel Dekker, New York; 1999:282-284.

[38] Ghosh A, Bhattacharyya BC. Biomethanation of white rotted and brown rotted rice straw. Bioprocess Engineering, Apr 1, 1999; 20(4):297-302.

[39] Dioha IJ, Ikeme CH, Nafi'u T, Soba NI, Yusuf MB. Effect of carbon to nitrogen ratio on biogas production. International Research Journal of Natural Sciences, Sep. 2013; 1:1.

[40] Arvanitoyannis Ioannis S, Persefoni T. Corn and rice waste: a comparative and critical presentation of methods and current and potential uses of treated waste. International Journal of Food Science \& Technology, 2008; 43(6):958-988.

[41] Schmidt JE, Ahring BK. Granular sludge formation in upflow anaerobic sludge blanket (UASB) reactors. Biotechnology and Bioengineering, Feb. 5, 1996; 49(3):229-246.

[42] Zhao X, Chen Z, Shen J, Wang X. Performance of aerobic granular sludge in different bioreactors. Environmental Technology, Apr. 18, 2014; 35(8):938-44.

[43] Wu J, Afridi ZU, Cao ZP, Zhang ZL, Poncin S, Li HZ, Zuo JE, Wang KJ. Size effect of anaerobic granular sludge on biogas production: a micro scale study. Bioresource Technology, Feb. 29, 2016; 202:165-171. 